DOI:

\title{
High Output Voltage Gain DC/DC Boost Converter Suitable for Renewable Energy Applications
}

\author{
Elwy E. El-Kholy ${ }^{1}$, AL-Hassan H. Amer ${ }^{2}$, Arafa S. Mansour ${ }^{1}$ \\ ${ }^{1}$ Electrical Engineering Department, Faculty of Engineering, Menoufia University, Egypt. \\ ${ }^{2}$ Master Degree Candidate (corresponding author: hassan_amer71@yahoo.com)
}

\begin{abstract}
High-voltage gain DC-DC boost converter is very important because it is required in many industrial applications, and therefore becomes the focus of all researches nowadays. Conventional topologies is used to obtain high gain due to its advantages such as simple structure, simple control, and low cost but it must be operated at extreme duty cycle in order to obtain high voltage gain which leads to high semiconductors voltage stress, high switching loss, and diode reverse recovery problems that degrades the system performance, and cause a significant efficiency reduction. Using of Cascaded boost converter and switched inductor converter solve some of the problems appeared with conventional boost converter as they have higher voltage gain without working with high duty cycle like conventional one, but they have some problems such as higher losses, and lower efficiency that also degrades the system performance. This study presents a new non-isolated high voltage gain DC $\backslash$ DC boost converter operating with a reasonable duty cycle by integrating dual boost converter with switched inductor structures. The presented converter operates with soft-switching ZVS mode for all switches, high voltage gain, and high efficiency. In order to prove the converter effectiveness, the theoretical analysis, operation principle, and simulation results are presented.
\end{abstract}

Keywords: Voltage gain, Boost, DC-DC, Dual boost, Switched inductor

\section{Introduction}

There is a great interest in renewable energy so that DC-DC converter with high voltage gain becomes necessary element in power conversion systems, because of an unregulated low-level DC voltage that needs to be stepped up to a higher-level using power electronic components to be suitable for practical applications such as uninterruptible power supplies, and photovoltaic systems [1].

The conventional boost converter is used to obtain high gain due to its advantages such as low cost, and simple structure but it is not suitable for the applications that needs high gain because the conventional boost converter needs to operate at large duty cycle, and a reverse-recovery problem appears [2].

Using of Cascaded boost converter and switched inductor converter solve some of the problems appeared with conventional boost converter as they have higher voltage gain without working with high duty cycle like conventional one, but they have some problems such as higher losses, and lower efficiency [3]. The use of isolated converter with a transformer such as forward converter overcomes the above problems, but it has some problems such as large size, and core saturation problem [4].

Another solution is to use multiple energy sources, the use of multilevel converter topologies such as the neutral-point clamped inverter [5].

Transformer-less DC-DC converter with large conversion ratios becomes an important subject of research in the past few decades, the circuits were extensions of the ĈUK converter with the advantages of high-power efficiency, and low switching losses, but extra capacitors require two extra transistors and one extra diode, and then large number of components [6].

A switched-capacitor stage was used along with a classical boost converter to have high gain. In particular, a $12-120 \mathrm{~V}_{\mathrm{dc}}$ output converter processing $35 \mathrm{~W}$ of power, operating at $100 \mathrm{kHz}$, was reported in [7].

The step-up switching-mode converter with high gain using a switched-capacitor circuit avoids diodereverse recovery problems, and good efficiency was proposed in [8], but this idea is only suitable for low power applications.

A modified high step-up non isolated DC-DC converter for PV systems with high gain, high 
efficiency, and low switching losses is presented in [9] where it has been designed for the input voltage of $15 \mathrm{Vdc}$ and an output of $150 \mathrm{~V}_{\mathrm{dc}}$ with switching frequency of $24 \mathrm{KHz}$ and $100 \mathrm{~W}$ output power, while having efficiency of $92.5 \%$ at full load, but Unfortunately the duty cycle is $(\mathrm{D}=0.8)$ and it still large value.

A switched inductor three-level DC-DC converter with high gain which converts the output voltage of the DC source into two voltage sources with the advantages of high efficiency, and low voltage semiconductors is presented in [10]. However, it's high voltage gain $\left(\mathrm{V}_{\mathrm{o}} / \mathrm{V}_{\text {in }}>7\right)$ occurs at duty cycle $(\mathrm{D}>0.6)$ which makes problems like diode reverse recovery.

In this paper, a new design of non-isolated highvoltage gain DC-DC boost converter by integrating dual boost converter with switched inductor structures is presented. The operating modes, analysis, and design of the proposed circuit is discussed. Simulation results are conducted to verify the validity of the proposed circuit.

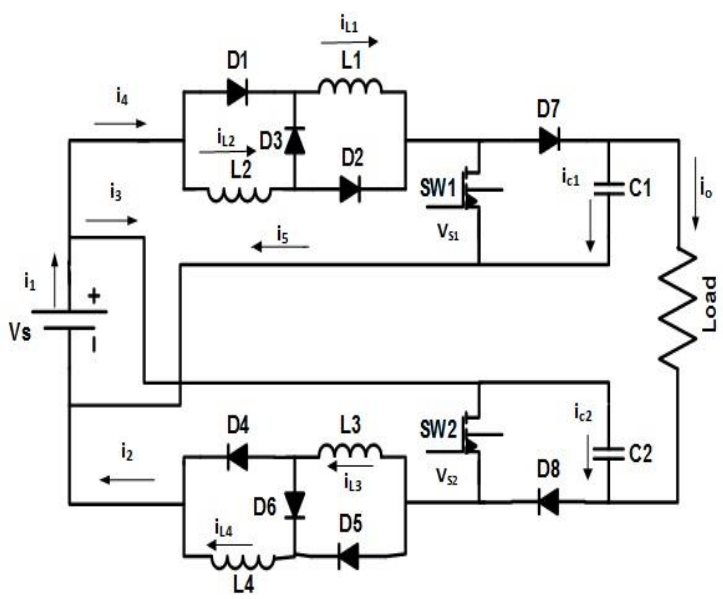

Figure 1- Circuit configuration of the proposed converter

\section{Circuit Description and Analysis}

The high-gain transformer-less double-boost converter with switched inductor topology is show in Fig. 1. In this section, a description of modes of operation at duty cycle $\mathrm{D}=0.5$ for the converter is introduced. For the analysis, the power losses are neglected. Since both converters are boost type, it is assumed that the output voltage across each capacitor $\mathrm{C}_{1}$ and $\mathrm{C}_{2}$ is higher than the input voltage source $\left(\mathrm{V}_{\mathrm{S}}\right)$. It is also assumed that the converter operates in the continuous conduction mode (CCM), both converters have identical duty cycles, and the output voltage for each converter has the same average value.

$$
\begin{aligned}
& \text { Duty Cycle } 1\left(D_{1}\right)=\text { Duty Cycle } 2\left(D_{2}\right)=D \\
& V_{C 1}=V_{C 2}
\end{aligned}
$$

\subsection{Operational modes}

There are four modes of operations:

- Mode 1: $0 \leq \mathrm{t} \leq \mathrm{t} 1$ ( $\mathrm{S} 1$ is in the on state and $\mathrm{S} 2$ is in the off state), (Fig. 2a):

In this mode, the switch $\left(\mathrm{S}_{1}\right)$ turns on, the switch $\left(\mathrm{S}_{2}\right)$ turns off, the diodes $\left(\mathrm{D}_{3}, \mathrm{D}_{4}, \mathrm{D}_{5}, \mathrm{D}_{7}\right)$ are reversed biased and the diodes $\left(\mathrm{D}_{1}, \mathrm{D}_{2}, \mathrm{D}_{6}, \mathrm{D}_{8}\right)$ are forward biased. The first switched inductors $\left(\mathrm{L}_{1}, \mathrm{~L}_{2}\right)$ are connected in parallel with each other and being charged through the input voltage source Vs and the current through them increases. The current through the second switched inductor $\left(\mathrm{L}_{3}, \mathrm{~L}_{4}\right)$ which connected in series with each other decreases and the voltage across it $\left(-\mathrm{V}_{\mathrm{c} 2}+\mathrm{V}_{\mathrm{S}}\right)$ as the diode $\mathrm{D}_{8}$ closes the circuit by becoming forward biased. The load current Io flows through the capacitor $C_{1}$ which is being discharged, and the input voltage source is in series with both the output capacitors and the load voltage is $\left(\mathrm{V}_{\mathrm{c} 1}+\mathrm{V}_{\mathrm{c} 2}-\mathrm{V}_{\mathrm{S}}\right)$.

By applying Kirchhoff's voltage and current laws, the voltage and current equations for this mode can be written as:

$\mathrm{V}_{\mathrm{s} 2}=\mathrm{V}_{\mathrm{c} 2} ; \mathrm{V}_{\mathrm{c} 1}=-\mathrm{V}_{\mathrm{D} 7} ; \mathrm{V}_{\mathrm{c} 2}=\mathrm{V}_{\mathrm{S}}+\mathrm{V}_{\mathrm{L} 3}+\mathrm{V}_{\mathrm{L} 4} ;$

$\mathrm{V}_{\mathrm{o}}=\mathrm{V}_{\mathrm{c} 1}+\mathrm{V}_{\mathrm{L} 3}+\mathrm{V}_{\mathrm{L} 4}=\mathrm{V}_{\mathrm{c} 1}+\mathrm{V}_{\mathrm{c} 2}-\mathrm{V}_{\mathrm{S}}$

$\mathrm{i}_{1}=\mathrm{i}_{3}+\mathrm{i}_{4} ; \mathrm{i}_{3}=\mathrm{i}_{\mathrm{c} 2} ; \mathrm{i}_{4}=\mathrm{i}_{\mathrm{L} 1}+\mathrm{i}_{\mathrm{L} 2}=\mathrm{i}_{\mathrm{S} 1}=\mathrm{i}_{5}$

$; \mathrm{i}_{\mathrm{c} 1}=\mathrm{i}_{\mathrm{o}}=\mathrm{i}_{2}-\mathrm{i}_{\mathrm{c} 2} ; \quad \mathrm{i}_{2}=\mathrm{i}_{\mathrm{L} 3}=\mathrm{i}_{\mathrm{L} 4}=\mathrm{i}_{\mathrm{C} 2}+\mathrm{i}_{\mathrm{o}}$

$; \mathrm{i}_{\mathrm{O}}=\mathrm{i}_{2}-\mathrm{i}_{3}=\mathrm{i}_{\mathrm{L} 3}-\mathrm{i}_{\mathrm{C} 2}=\mathrm{i}_{\mathrm{C} 1}$

- Mode 2: $\mathrm{t} 1 \leq \mathrm{t} \leq \mathrm{t} 2$ ( $\mathrm{S} 1$ is still in the on state and $\mathrm{S} 2$ is still in the off state), (Fig. 2b):

In this mode, the switch $\left(S_{1}\right)$ is still turn on, the switch $\left(S_{2}\right)$ is still turn off, the diodes $\left(D_{3}, D_{4}, D_{5}, D_{6}\right.$, $\left.\mathrm{D}_{7}, \mathrm{D}_{8}\right)$ are reversed biased and the diodes $\left(\mathrm{D}_{1}, \mathrm{D}_{2}\right)$ are forward biased. The first switched inductors $\left(\mathrm{L}_{1}\right.$, $\mathrm{L}_{2}$ ) are still connected in parallel with each other and being charged through the input voltage source Vin and the current through them still increasing. The current through the second switched inductor $\left(\mathrm{L}_{3}, \mathrm{~L}_{4}\right)$ became zero as the diodes $\left(\mathrm{D}_{6}, \mathrm{D}_{8}\right)$ are reversed biased. The load current $\mathrm{I}_{\mathrm{o}}$ flows through the capacitor $C_{1}$ and the capacitor $C_{2}$ which are being discharged, and the input voltage source is in series with both the output capacitors and the load voltage is $\left(\mathrm{V}_{\mathrm{c} 1}+\mathrm{V}_{\mathrm{c} 2}-\mathrm{V}_{\mathrm{S}}\right)$. The voltage and current equations for this mode can be written as:

$$
\begin{gathered}
\mathrm{V}_{\mathrm{o}}=\mathrm{V}_{\mathrm{c} 1}+\mathrm{V}_{\mathrm{c} 2}-\mathrm{V}_{\mathrm{S}} \\
\mathrm{i}_{4}=\mathrm{i}_{3}+\mathrm{i}_{1}=\mathrm{i}_{5}=\mathrm{i}_{\mathrm{S} 1}=\mathrm{i}_{\mathrm{L} 1}+\mathrm{i}_{\mathrm{L} 2} ; \mathrm{i}_{\mathrm{L} 1}=\mathrm{i}_{\mathrm{L} 2} ; \\
\mathrm{i}_{\mathrm{o}}=\mathrm{i}_{\mathrm{c} 1}=\mathrm{i}_{\mathrm{c} 2}=\mathrm{i}_{3}=\mathrm{i}_{5}-\mathrm{i}_{1}=\mathrm{i}_{\mathrm{L} 1}+\mathrm{i}_{\mathrm{L} 2}-\mathrm{i}_{1}
\end{gathered}
$$

- Mode 3: $\mathrm{t} 2 \leq \mathrm{t} \leq \mathrm{t} 3$ ( $\mathrm{S} 1$ is in the off state $\mathrm{S} 2$ is in the on state), (Fig. 2c):

In this mode, the switch $\left(\mathrm{S}_{1}\right)$ is off and the switch $\left(\mathrm{S}_{2}\right)$ 


\section{Elwy E. El-Kholy', Arafa S. Mansour ${ }^{I}$, AL-Hassan H. Amer " "High Output Voltage Gain DC/DC Boost Converter Suitable for Renewable Energy Applications "}

is on. The diodes $\left(\mathrm{D}_{1}, \mathrm{D}_{2}, \mathrm{D}_{6}, \mathrm{D}_{8}\right)$ are reversed biased and the diodes $\left(\mathrm{D}_{3}, \mathrm{D}_{4}, \mathrm{D}_{5}, \mathrm{D}_{7}\right)$ are forward biased. The first switched inductors $\left(\mathrm{L}_{1}, \mathrm{~L}_{2}\right)$ are connected in series with each other, the voltage across them is ($\mathrm{V}_{\mathrm{c} 1}+\mathrm{V}_{\mathrm{S}}$ ) as the diode $\mathrm{D}_{7}$ closes the circuit by becoming forward biased and the current through them decreases. The second switched inductor $\left(\mathrm{L}_{3}\right.$, $\mathrm{L}_{4}$ ) connected in parallel with each other to the input voltage source, the voltage across them $\left(\mathrm{V}_{\mathrm{S}}\right)$ and the current through them starts to increase. The load current $I_{0}$ flows through the capacitor $C_{2}$ which is being discharged, and the input voltage source is in series with both the output capacitors and the load voltage is $\left(\mathrm{V}_{\mathrm{c} 1}+\mathrm{V}_{\mathrm{c} 2}-\mathrm{V}_{\mathrm{S}}\right)$. The voltage and current equations for this mode can be written as:

$\mathrm{V}_{\mathrm{S} 1}=\mathrm{V}_{\mathrm{C} 1} ; \mathrm{V}_{\mathrm{C} 2}=-\mathrm{V}_{\mathrm{D} 8} ; \mathrm{V}_{\mathrm{C} 1}=\mathrm{V}_{\mathrm{S}}+\mathrm{V}_{\mathrm{L} 1}+\mathrm{V}_{\mathrm{L} 2} ;$

$\mathrm{V}_{0}=\mathrm{V}_{\mathrm{C} 2}+\mathrm{V}_{\mathrm{L} 1}+\mathrm{V}_{\mathrm{L} 2} ; \mathrm{V}_{\mathrm{o}}=\mathrm{V}_{\mathrm{c} 1}+\mathrm{V}_{\mathrm{c} 2}-\mathrm{V}_{\mathrm{S}}$

$\mathrm{i}_{1}=\mathrm{i}_{3}+\mathrm{i}_{4} ; \mathrm{i}_{3}=\mathrm{i}_{\mathrm{S} 2}-\mathrm{i}_{\mathrm{c} 2} ; \mathrm{i}_{\mathrm{S} 2}=\mathrm{i}_{3}+\mathrm{i}_{\mathrm{C} 2}=\mathrm{i}_{\mathrm{L} 3}+\mathrm{i}_{\mathrm{L} 4}=\mathrm{i}_{2}$

$\mathrm{i}_{4}=\mathrm{i}_{\mathrm{L} 1}=\mathrm{i}_{\mathrm{L} 2}=\mathrm{i}_{\mathrm{C} 1}+\mathrm{i}_{\mathrm{o}} ; \mathrm{i}_{\mathrm{o}}=\mathrm{i}_{\mathrm{C} 2}=\mathrm{i}_{\mathrm{L} 1}-\mathrm{i}_{\mathrm{C} 1}$

- Mode 4: $\mathrm{t} 3 \leq \mathrm{t} \leq \mathrm{Ts}$ ( $\mathrm{S} 1$ is still in the off $\mathrm{S} 2$ on),

(Fig. 2d):

In this mode, the switch (S1) still off and the switch (S2) still on. The diodes $\left(\mathrm{D}_{1}, \mathrm{D}_{2}, \mathrm{D}_{3}, \mathrm{D}_{6}, \mathrm{D}_{7}, \mathrm{D}_{8}\right)$ are reversed biased and the diodes $\left(D_{4}, D_{5}\right)$ are forward biased. The current through the first switched inductor $\left(\mathrm{L}_{1}, \mathrm{~L}_{2}\right)$ becomes zero as the diodes $\left(\mathrm{D}_{3}, \mathrm{D}_{7}\right)$ are reversed biased. The second switched inductor $\left(\mathrm{L}_{3}, \mathrm{~L}_{4}\right)$ are still connected in parallel with each other and being charged through the input voltage source $\mathrm{V}_{\mathrm{S}}$ and the current through them still increasing.

The load current $I_{0}$ flows through the capacitor $C_{1}$ and the capacitor $\mathrm{C}_{2}$ which are being discharged, and the input voltage source is in series with both the output capacitors and the load voltage is $\left(\mathrm{V}_{\mathrm{c} 1}+\mathrm{V}_{\mathrm{c} 2}-\right.$ $\mathrm{V}_{\mathrm{S}}$ ).

$\mathrm{V}_{\mathrm{o}}=\mathrm{V}_{\mathrm{c} 1}+\mathrm{V}_{\mathrm{c} 2}-\mathrm{V}_{\mathrm{S}}$

$\mathrm{i}_{1}=\mathrm{i}_{3}=\mathrm{i}_{\mathrm{S} 2}-\mathrm{i}_{\mathrm{C} 2} ; \mathrm{i}_{\mathrm{L} 3}=\mathrm{i}_{\mathrm{L} 4} ; \mathrm{i}_{\mathrm{C} 1}=\mathrm{i}_{\mathrm{C} 2}=\mathrm{i}_{0}$;

$\mathrm{i}_{0}=\mathrm{i}_{\mathrm{S} 2}-\mathrm{i}_{1} ; \mathrm{i}_{\mathrm{S} 2}=\mathrm{i}_{2}=\mathrm{i}_{\mathrm{L} 3}+\mathrm{i}_{\mathrm{L} 4} ; \mathrm{i}_{0}=\mathrm{i}_{\mathrm{L} 3}+\mathrm{i}_{\mathrm{L} 4}-\mathrm{i}_{1}$

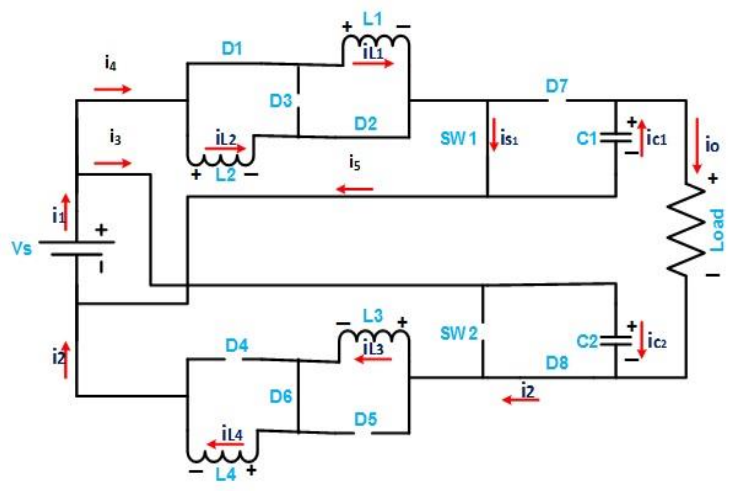

(a)

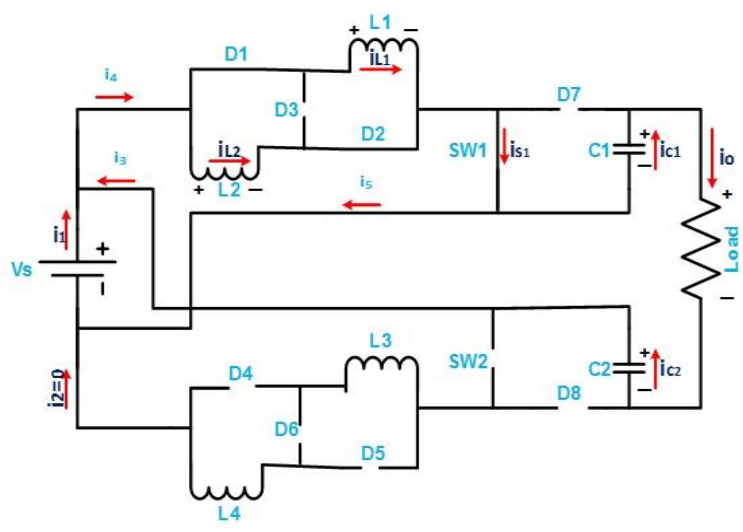

(b)

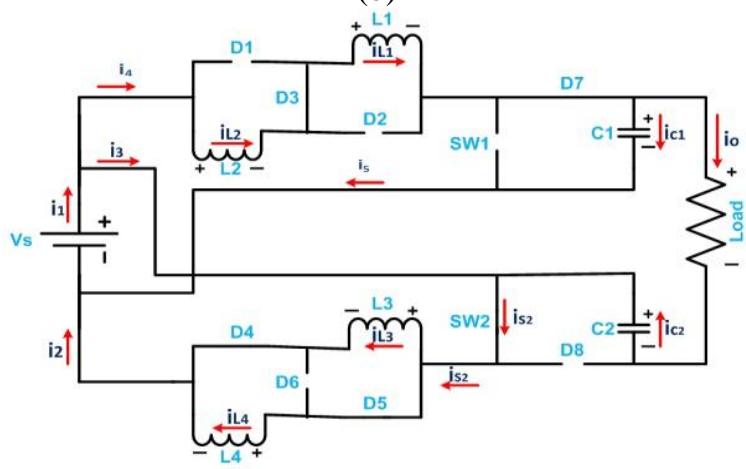

(c)

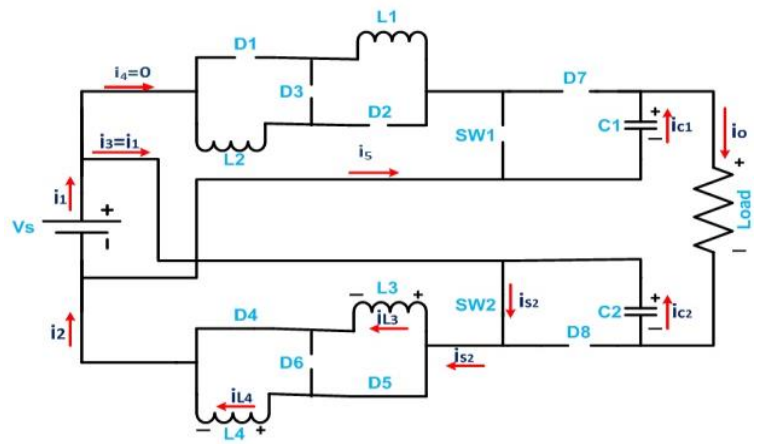

(d)

Figure- 2. Operation modes of the proposed converter (a) Mode 1, (b) Mode 2, (c) Mode 3 and (d) Mode 4

\subsection{Converter Analysis}

Under assumption of each module operates in the CCM and it is a separate boost converter. Therefore, the voltages across the output capacitors are equals $\left(\mathrm{V}_{\mathrm{C} 1}=\mathrm{V}_{\mathrm{C} 2}\right)$.

For one converter: during the on-state, the switch (S) is closed, which makes the input voltage $\left(\mathrm{V}_{\mathrm{S}}\right)$ appear across the switched inductors, which causes a change in current $\left(\mathrm{I}_{\mathrm{L}}\right)$ flowing through the switched inductors during a time period $(\mathrm{t})$ by the formula:

$\Delta \mathrm{I}_{\mathrm{L}}=(1 / \mathrm{L}) \mathrm{V}_{\text {in }} \Delta \mathrm{t}$

Where $\mathrm{L}$ is the equivalent inductance of switched 
inductors.

At the end of the on-state, the increase of $\mathrm{I}_{\mathrm{L}}$ is:

$\Delta \mathrm{I}_{\mathrm{L}-\text { on }}=(1 / \mathrm{L}) \int_{0}^{D T} \operatorname{Vin} \Delta \mathrm{t}=(2 / \mathrm{L}) \mathrm{V}_{\text {in }}(\mathrm{DT}-0)$

$\Delta \mathrm{I}_{\mathrm{L}-\text { on }}=\left(2 \mathrm{~V}_{\text {in }} \backslash \mathrm{L}\right) \mathrm{DT} ; \mathrm{V}_{\text {in }}=\mathrm{V}_{\mathrm{S}}$

During the off-state, the switch $(\mathrm{S})$ is open, so the inductor current flows through the load, if we consider zero voltage drop in the diode, and the capacitor id large enough for its voltage to remain constant, the evolution of $\left(\mathrm{I}_{\mathrm{L}}\right)$ is:

$\mathrm{V}_{\text {in }}-\mathrm{V}_{\mathrm{c}}=\mathrm{L}\left(\mathrm{di}_{\mathrm{L}} \backslash \mathrm{dt}\right)$

Therefore, the variation of $\left(\mathrm{I}_{\mathrm{L}}\right)$ during the off-period is: $\Delta \mathrm{I}_{\mathrm{L}-\text { off }}=(1 \mathrm{~L}) \int_{D T}^{T}(\mathrm{Vin}-\mathrm{Vc}) \Delta \mathrm{t}=\frac{(\operatorname{Vin}-\mathrm{Vo})}{2 \mathrm{~L}}(\mathrm{~T}-\mathrm{DT})+\mathrm{k}$

$\Delta \mathrm{I}_{\mathrm{L}-\text { off }}=((\mathrm{VC}-\mathrm{Vin}) \backslash 2 \mathrm{~L}) * \mathrm{~T} *(1-\mathrm{D})+\left(\mathrm{V}_{\mathrm{in}} \mathrm{D} / \mathrm{L}\right) \mathrm{T}$

As we consider that the converter operates in steadystate conditions, the amount of energy stored in each of its components has to be the same at the beginning and at the end of commutation cycle. In particular, the energy stored in the inductor is given by:

$$
\mathrm{E}=(1 \backslash 2) \mathrm{L} \mathrm{I}_{\mathrm{L}}^{2}
$$

So, the inductor current has to be the same at the start and end of the commutation cycle.

This means the overall change in the current (the sum of the changes) is zero:

$$
\Delta \mathrm{I}_{\mathrm{L}-\mathrm{on}}+\Delta \mathrm{I}_{\mathrm{L}-\mathrm{off}}=0
$$

Substituting $\Delta \mathrm{I}_{\mathrm{L}-\mathrm{on}}$ and $\Delta \mathrm{I}_{\mathrm{L}-\mathrm{off}}$ by their expressions yields:

$$
\begin{gathered}
\left(2 \mathrm{~V}_{\text {in }} \backslash \mathrm{L}\right) \mathrm{DT}+\left[\left(\mathrm{V}_{\text {in }}-\mathrm{V}_{\mathrm{c}}\right) \backslash 2 \mathrm{~L}\right] \mathrm{T}(1-\mathrm{D})+\left(\mathrm{V}_{\text {in }} \mathrm{D} / \mathrm{L}\right) \mathrm{T} \\
=0
\end{gathered}
$$

$(\mathrm{Vc} \backslash \mathrm{Vin})=[(1+4 \mathrm{D}) \backslash(1-\mathrm{D})]$

The voltage across the output capacitors $C_{1}$ and $C_{2}$ can be expressed as:

$\mathrm{V}_{\mathrm{c} 1}=\mathrm{V}_{\mathrm{c} 2}=[(1+4 \mathrm{D}) \backslash(1-\mathrm{D})] \mathrm{V}_{\text {in }}$

As we will explain through the description of the various modes of operation, the two output capacitors are always in series with the input voltage source and therefore the output voltage can be expressed as:

$\mathrm{V}_{\mathrm{o}}=\mathrm{V}_{\mathrm{c} 1}+\mathrm{V}_{\mathrm{c} 2}-\mathrm{V}_{\text {in }}$

From eqs. (16) and (17), the voltage gain of the proposed converter can be obtained by:

Vo $\backslash$ Vin $=[(1+9 D) \backslash(1-D)]$

The input current can be obtained from applying Kirchhoff's current law on the input side in Fig. 1:

$\mathrm{i} 1=\mathrm{i} 3+\mathrm{i} 4 ; \mathrm{i} 2=\mathrm{i} 3+\mathrm{io}$

$\mathrm{i} 1=\mathrm{i} 2+\mathrm{i} 4-\mathrm{io} ; \mathrm{i} 2=\mathrm{i} 3+\mathrm{io}$
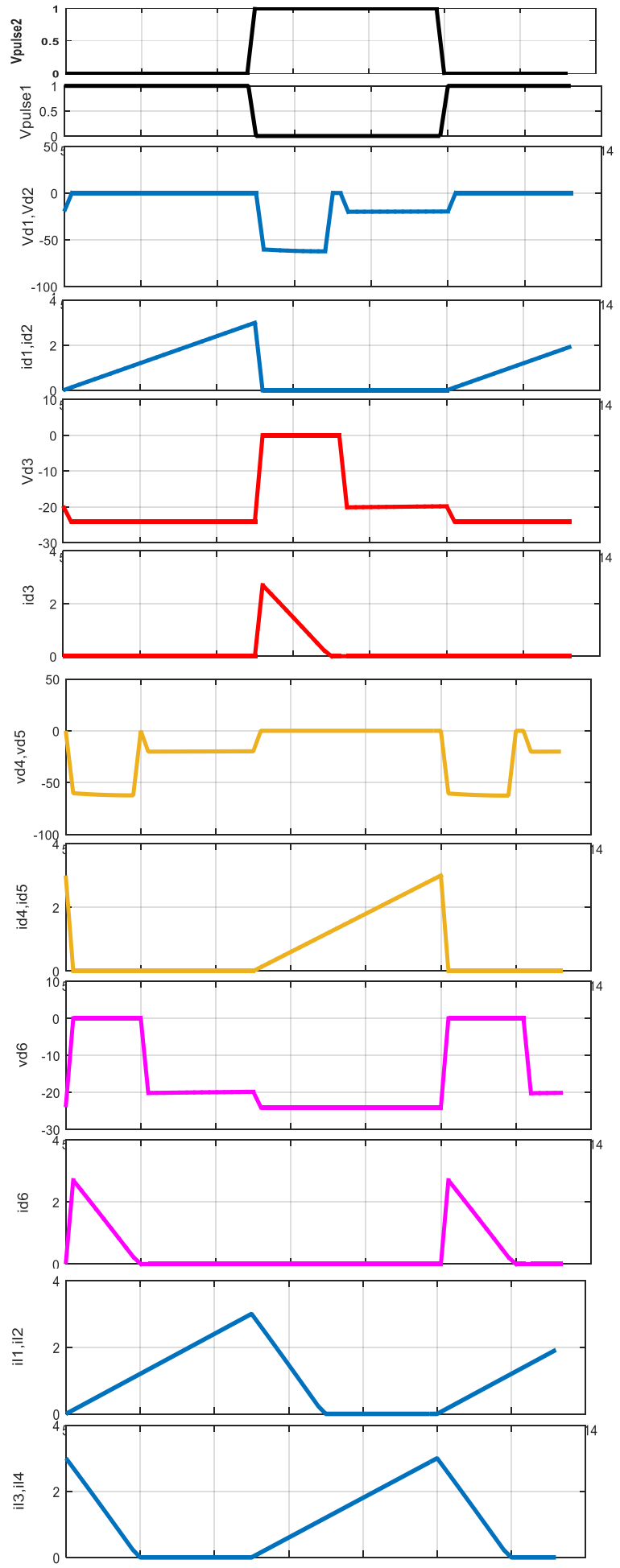
Elwy E. El-Kholy ${ }^{1}$, Arafa S. Mansour", AL-Hassan H. Amer " "High Output Voltage Gain DC/DC Boost Converter Suitable for Renewable Energy Applications "

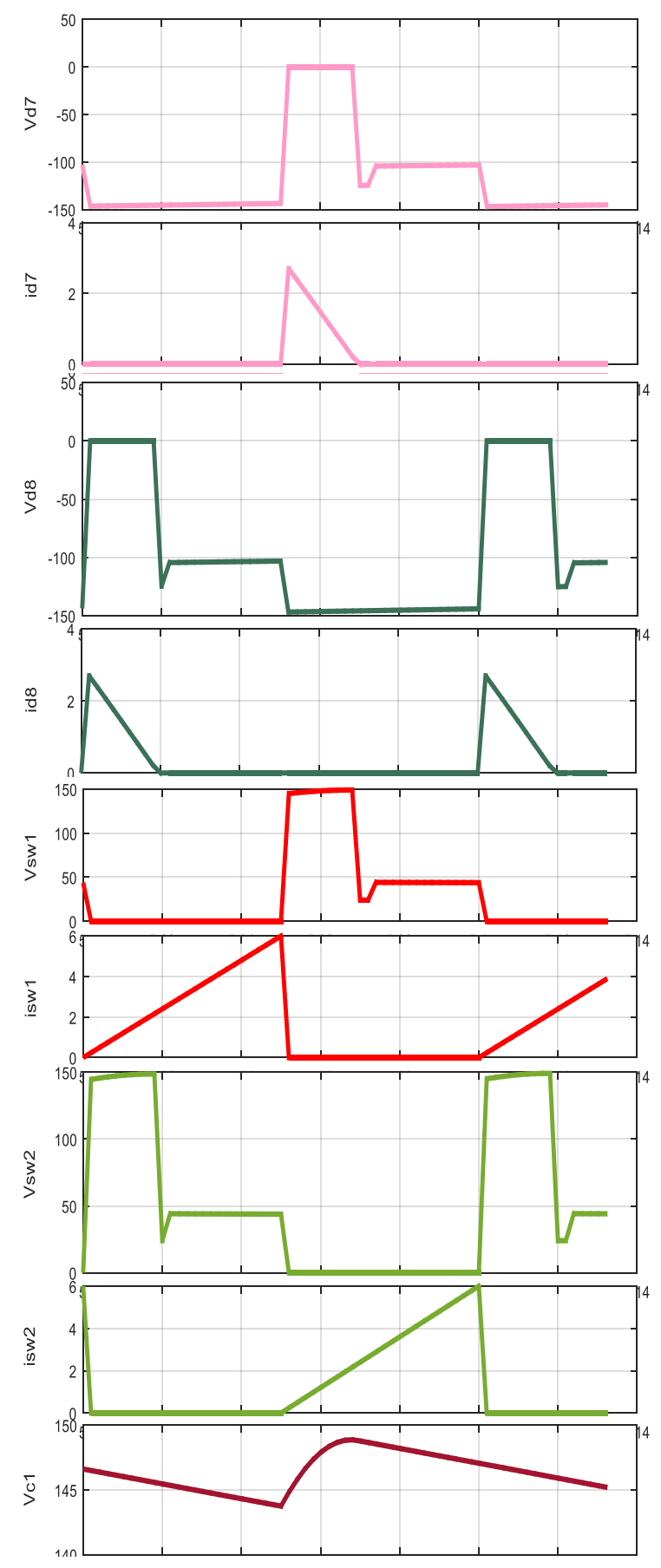

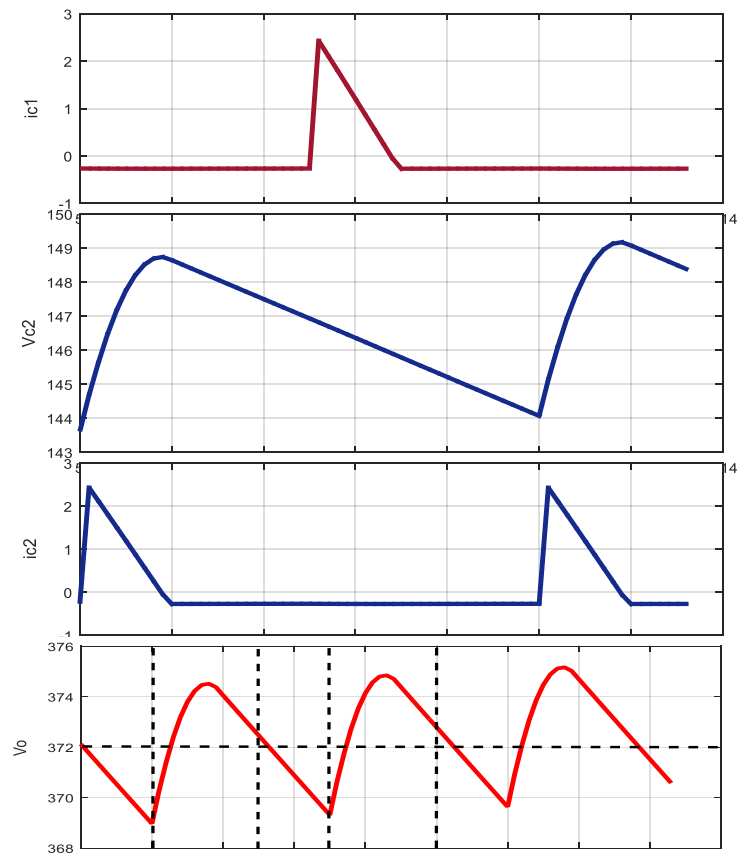

Figure 3- Key waveforms of the proposed converter

$$
\text { for }(D=0.5)
$$

\section{Simulation Results}

The duty cycle is calculated to be (0.5). The key operating waveforms of the converter with the specifications provided in Table (1) generated through computer simulation are presented in Fig. 3. PSIM software has been used to generate the waveforms and the presented results. Figs. 4 and 5 illustrate the effectiveness and the good performance of the proposed circuit.

Table 1- Converter component specifications

\begin{tabular}{lc}
\hline \multicolumn{1}{c}{ Devices } & Value \\
\hline Inductances $\left(\mathrm{L}_{1}, \mathrm{~L}_{2}, \mathrm{~L}_{3}, \mathrm{~L}_{4}\right)$ & $400 \mu \mathrm{H}$ \\
\hline Capacitances $\left(\mathrm{C}_{1}, \mathrm{C}_{2}\right)$ & $4.7 \mu \mathrm{F}$ \\
\hline Power switches $\left(\mathrm{S}_{1}, \mathrm{~S}_{2}(\right.$ & $\begin{array}{c}\mathrm{N} \leqslant \varepsilon \mathrm{FDH} \\
0 .\end{array}$ \\
\hline Diodes $\left(\mathrm{D}_{1}, \mathrm{D}_{2}, \mathrm{D}_{3}, \mathrm{D}_{4}, \mathrm{D}_{5}, \mathrm{D}_{6}, \mathrm{D}_{7}, \mathrm{D}_{8}\right)$ & $\begin{array}{c}\mathrm{RHRG} \\
0.7 .\end{array}$ \\
\hline Input voltage $\left(\mathrm{V}_{\mathrm{S}}\right)$ & $24 \mathrm{~V}$ \\
\hline Output voltage $\left(\mathrm{V}_{\mathrm{O}}\right)$ & $272 \mathrm{~V}$ \\
\hline Switching frequency $\left(\mathrm{F}_{\mathrm{S}}\right)$ & $\mathrm{KHz} 10$ \\
\hline Duty Cycle $(\mathrm{D})$ & 0.5 \\
\hline
\end{tabular}




\section{Elwy E. El-Kholy, Arafa S. Mansour, AL-Hassan H. Amer "High Output Voltage Gain DC/DC Boost Converter Suitable for Renewable Energy Applications"}

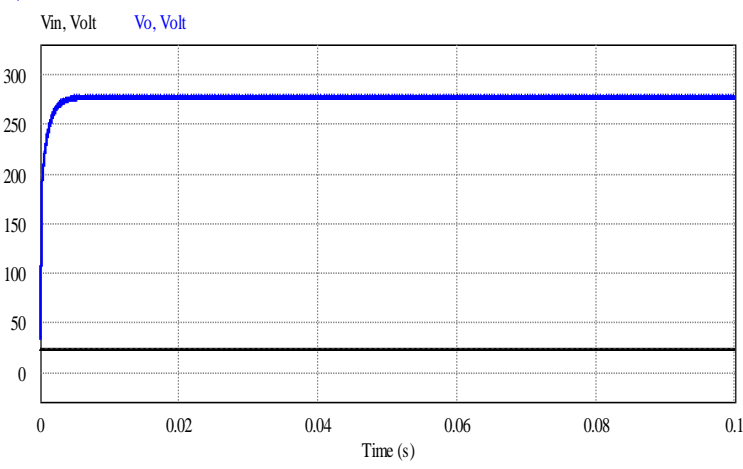

Figure 4- Input and Output Voltages of the proposed converter

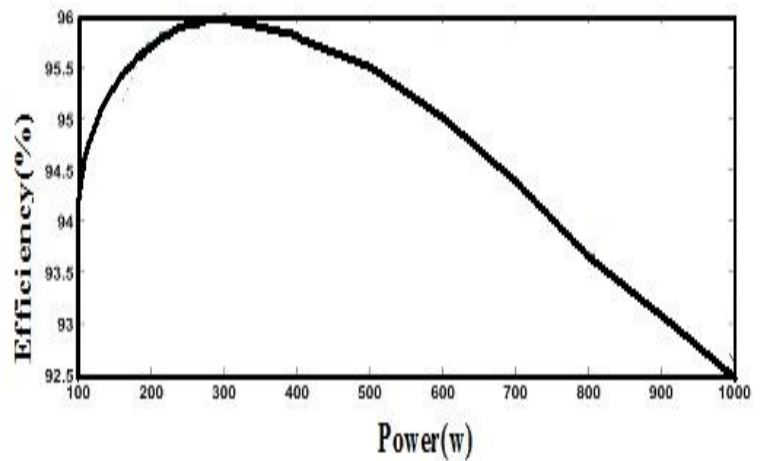

Figure 5- Measured efficiency of the proposed converter

Table 2-Comparison between previous techniques and the proposed one

\begin{tabular}{|c|c|c|c|c|c|}
\hline & & $\begin{array}{c}\text { Single boost } \\
\text { converter } \\
(\mathrm{D}=0.825) \\
\\
{[11]}\end{array}$ & $\begin{array}{c}\text { Two-interleaved } \\
\text { boost converter } \\
(\mathrm{D}=0.825) \\
{[11]}\end{array}$ & $\begin{array}{c}\text { Floating output } \\
\text { interleaved input boost } \\
\text { converter } \\
(\mathrm{D}=0.7) \\
{[11]}\end{array}$ & $\begin{array}{c}\text { The proposed } \\
\text { converter } \\
(\mathrm{D}=0.32)\end{array}$ \\
\hline \multirow[b]{4}{*}{ Switches } & Number & 1 & 2 & 2 & 2 \\
\hline & $\mathrm{V}_{\mathrm{pk}}(\mathrm{V})$ & 200 & 200 & 119 & 118 \\
\hline & $\mathrm{I}_{\mathrm{rms}}(\mathrm{A})$ & 26 & 13 & 14 & 9.4 \\
\hline & $\begin{array}{l}\text { Switch } \\
\text { utilization } \\
\text { factor } \\
\left(\frac{V o * I o}{n * \mathrm{Vpk} * \mathrm{Ipk}}\right)\end{array}$ & 0.17 & 0.32 & 0.48 & 0.45 \\
\hline \multirow[b]{4}{*}{ Diodes } & Number & 1 & 2 & 2 & 8 \\
\hline & $\mathrm{V}_{\mathrm{pk}}(\mathrm{V})$ & 200 & 200 & 119 & 117 \\
\hline & $\mathrm{I}_{\mathrm{rms}}(\mathrm{A})$ & 5 & 2.5 & 5 & 4.2 \\
\hline & $\begin{array}{c}\text { Diode } \\
\text { utilization } \\
\text { factor } \\
\left(\frac{V o * I o}{n * \mathrm{Vpk} * \mathrm{Ipk}}\right)\end{array}$ & 0.17 & 0.32 & 0.48 & 0.25 \\
\hline \multirow{4}{*}{ Inductors } & Number & 1 & 2 & 2 & 4 \\
\hline & $\mathrm{L}$ & $562 \mu \mathrm{H} \times 1$ & $450 \mu \mathrm{H} \times 2$ & $300 \mu \mathrm{H} \times 2$ & $400 \mu \mathrm{H} \times 4$ \\
\hline & $\mathrm{I}_{\mathrm{rms}}(\mathrm{A})$ & 28.6 & 14.3 & 16.7 & 8.5 \\
\hline & $\begin{array}{c}\text { Total Energy } \\
\text { Volume } \\
\left(\mathrm{LI}^{2}\right) \\
\end{array}$ & 0.46 & 0.18 & 0.16 & 0.115 \\
\hline \multirow{4}{*}{ Capacitors } & Number & 1 & 1 & 2 & 2 \\
\hline & $\mathrm{C}$ & $35 \mu \mathrm{F} \times 1$ & $15 \mu \mathrm{F} \times 1$ & $17 \mu \mathrm{F} \times 2$ & $4.7 \mu \mathrm{F} \times 2$ \\
\hline & $\mathrm{V}_{\mathrm{avr}}(\mathrm{V})$ & 200 & 200 & 117 & 120.3 \\
\hline & $\begin{array}{c}\text { Total Energy } \\
\text { Volume } \\
\left(\mathrm{CV}^{2}\right) \\
\end{array}$ & 1.4 & 0.6 & 0.46 & 0.136 \\
\hline
\end{tabular}




\section{Elwy E. El-Kholy', Arafa S. Mansour ${ }^{I}$, AL-Hassan H. Amer " High Output Voltage Gain DC/DC Boost Converter Suitable for Renewable Energy Applications "}

To validate the good performance of the proposed circuit, a comparison between previous techniques and the proposed circuit is introduced in Table 2.

The comparison is performed for the following specifications: $\mathrm{V}_{\mathrm{in}}=35 \mathrm{~V}_{\mathrm{dc}} ; \mathrm{V}_{\mathrm{o}}=200 \mathrm{~V}_{\mathrm{dc}} ; \mathrm{F}_{\mathrm{S}}=60$ $\mathrm{KHz}$ for all converters.

\subsection{From the information presented in Table (2), the following observations can be made:}

- The switch and diode voltage ratings of the proposed converter are $59 \%$ and $58.5 \%$ of those of the conventional converters, but the switch and diode voltage ratings of the proposed converter is $99.1 \%$ and $98.3 \%$ of the interleaved-input boost-derived DC-DC high-gain transformer-less converter. Therefore, lower on-drop devices can be achieved for the proposed converter, leading to reduced conduction losses.

- The switch utilization factor are 2.64 times and 1.4 times higher than those of the single boost converter and the two-interleaved boost converter, respectively, and the switch utilization factor is 0.94 times of the interleaved-input boost-derived DC-DC high-gain transformer-less converter. Therefore, the cost of the switching devices of the proposed converter is the lower than of the single boost converter and the twointerleaved boost converter.

- The diodes utilization factors are $1.47,0.78$, and 0.52 times of those of the single boost converter, the two-interleaved boost converter, and the interleavedinput boost-derived DC-DC high-gain transformerless converter, respectively. This is because there are 8 diodes in the proposed converter.

- Since the input currents are divided, the total inductor energy volumes of the proposed converter is less than of that of the single boost converter by 4 times, and less than of the two interleaved boost converter by 1.56 times, and less than of the interleaved-input boost-derived DC-DC high-gain transformer-less converter by 1.39 times even though it require four inductors.

- The capacitor voltage rating of the proposed converter is $60.15 \%$ of those of the conventional converter and two-interleaved boost converter, and $102.8 \%$ of the interleaved-input boost-derived DCDC high-gain transformer-less converter. Even though the proposed converter requires two capacitors, the total energy volume of the capacitor is only $9.7 \%, 22.7 \%$, and $29.6 \%$ of the single boost converter, the two-interleaved boost converter, and the interleaved-input boost-derived DC-DC highgain transformer-less converter, respectively.
- Therefore, the volume and cost of the proposed converter will be reduced compared to the single boost converter even though it requires four times as many components. Moreover, when compared to the conventional boost converter, the proposed converter shows higher switch and diode utilization factors and lower energy volume of the passive components since it requires smaller duty cycle for the same design specification, and when compared to two interleaved boost converter, the proposed converter shows higher switch utilization factor, but lower diode utilization factor and lower energy volume of the passive components since it requires smaller duty cycle for the same design specification. Also, when compared to the interleaved-input boost-derived DCDC high-gain transformer-less converter, the proposed converter shows a lower switch and diode utilization factors by a small difference and lower energy volume of the passive components since it requires smaller duty cycle for the same design specification.

\section{Conclusions}

A new high voltage gain converter with continuous input current has been proposed. The analysis and design of the basic high-gain interleaved boost converter with switched inductors are also provided. The proposed DC-DC converter is a non-isolated one, which extends the voltage from $24 \mathrm{~V}_{\mathrm{dc}}$ input voltage to $272 \mathrm{~V}_{\mathrm{dc}}$ output voltage at power rating of $69 \mathrm{~W}$ without using transformer which reduces the voltage stress of the switches, provides low input current ripple and raises the overall efficiency, but it has 4 inductors and 8 diodes which affect the price of the converter. Simulation results taken from a PSIM software operating at $10 \mathrm{kHz}$, and duty cycle, D, equal to 0.5 to confirm the principles of operation of the converter. Thus, the idea of integrating converters in a single-stage seems to be promising on the path to obtain additional topologies feasible to photovoltaic and fuel cell applications. 


\section{References}

[1] F. Blaabjerg, Z. Chen, S. B. Kjaer, "Power electronics as efficient interface in dispersed power generation systems", IEEE Trans. Power Electron., Vol. 19, No. 5, September 2004, pp. 1184-1194.

[2] H. Renaudineau, J.p. Martin, B. NahidMobarakeh, S. Pierfederici, "DC-DC Converters Dynamic Modelling with State Odserver-Based Parameter Estimation" IEEE Trans. Power Electron., Vol. 30, No. 6, June 2015, pp. 33563363.

[3] R. Haroun, A. El Aroudi, et al., "Impedance matching in photovoltaic systems using cascaded boost converters and sliding mode control", IEEE Trans. Power Electron. Vol. 30, No. 6, June 2015, pp. 3185-3199.

[4] Y. Xue, L. Chang, S. B. Kjaer., J. Bordonau, T. Shimizu, "Topologies of single-phase inverters for small distributed power generators: an overview", IEEE Trans. Power Electron, Vol. 19, No. 5, September 2004, pp. 1305- 1314.

[5] M. Reinhardt, P. Mutschler, "Inverters without transformer in grid connected photovoltaic applications". Proc. 6th European Conf. on Power Electronics and Applications (EPE'95), Sevilla, vol. 3, September 1995, pp. 3086-3091.

[6] R. D. Middlebrook, "Transformer less DC-to-DC converters with large conversion ratios", IEEE Trans. Power Electron, Vol. 3, No. 4, October 1988, pp. 484-488.
[7] G.V.T. Bascope, I. Barbi, "Generation of a family of non-isolated DC-DC PWM converters using new three-state switching cells", IEEE 31st Ann. Power Electron. Spec. Conf., Galway, Ireland, June 2000, pp. 858-863.

[8] O. Abutbul, A. Gherlitz, Y. Berkovich, A. Ioinovici, "Boost converter with high voltage gain using a switched capacitor circuit", IEEE Int. Symp. on Circuits and Systems, ISCAS June 2003, pp. 296-299.

[9] S. Saravanan, N. R. Babu, "A modified high stepup non isolated DC-DC converter for PV application", journal of applied research and technology, Vol. 15, No. 1, June 2017.

[10] E. Salary, M. R. Banaei, A. Ajami, "Analysis of Switched Inductor Three-Level DC/DC Converter", Journal of Operation and Automation in Power Engineering, PESC'00, Vol. 6, No. 1, June 2018, pp.126-134.

[11] S. Choi, V.G. Agelidis, J. Yang, D. Coutellier, P. Marabeas,"Analysis, design and experimental results of a floating-output interleaved-input boost-derived DC-DC high-gain transformer-less converter", IET Power Electronics, Vol. 4, No.1, February 2011, pp. 168-180. 